\section{In-hospital Mortality after Liver Transplantation due to COVID-19}

Sir,

The impact of coronavirus disease 2019 (COVID-19) on early post-liver transplant outcomes remains unclear. There is very limited data reporting mortality in patients after liver transplantation (LT). Bhoori et al. have reported 3 posttransplant mortalities attributed to COVID-19. ${ }^{1}$ All patients were older than 65 years, had comorbidities, and died more than 10 years after LT. Webb et al. reported on 9 COVID-19related deaths in 39 positive patients. ${ }^{2}$ All mortalities occurred at leastone year after LT.

In Pakistan, most transplant centres either stopped or minimised liver transplant activity during March and April 2020, due to speculations regarding the impact of COVID-19 on surgical patients. With resumption of transplant activity, COVID-19 polymerase chain reaction (PCR) testing is performed two days prior to transplantation with computed tomography (CT) chest. In patients with a positive result, $L T$ is delayed until PCR is negative for COVID-19. Transplant activity has been limited to high-risk patients such as those with acute liver failure, acute on chronic liver failure, and patients with high MELD scores due to high risk of death on the waiting list. ${ }^{3}$ The risk of testing positive for COVID-19 after a negative preoperative PCR and its impact on early post-transplant outcomes is not reported. Here, we report post-transplant mortality due to COVID-19 in the early postoperative period (within 30 days) in a patient negative for COVID-19 preoperatively.

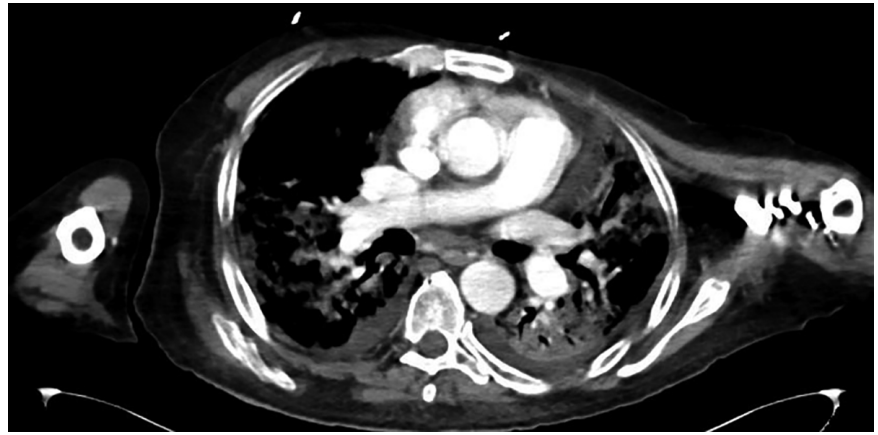

Figure 1: Post-transplant week 3, CT chest in COVID-19 positive patient.

A 49-year male, with end-stage liver disease secondary to nonB/non-C cirrhosis, no comorbids, and MELD score of 28, underwent LT in May 2020. His pre-transplant course was complicated by repeated intensive care admissions due to portosystemic encephalopathy, hemetemesis, ascites, and sepsis. He underwent three successive weekly COVID-19 PCR tests before transplantation, which were reported negative. His operative and postoperative course was uneventful until he developed shortness of breath on $11^{\text {th }}$ postoperative day (POD) and died on POD 27. Patient received low dose immunosuppression including steroids, broad spectrum antibiotics, antifungals and enoxaparin. Post-transplant COVID-19 PCR was positive and CT chest was typical for COVID-19 pneumonia (Figure 1). His D-dimers, CRP and ferritin were persistently raised. Details of the postoperative course are shown in Table 1.

Throughout the post-transplant course, his liver function tests remained within normal range and he had no systemic signs of infection. Regarding the source of COVID-19, one of the family members tested positive for COVID-19 PCR and was in close contact with the patient before he was admitted for transplantation.

Table i: Sequence of events after patient tested positive for COVID-19 in the immediate post-transplant period.

\begin{tabular}{|c|c|c|c|}
\hline $\begin{array}{l}\text { Events } \\
\text { (postoperative day) }\end{array}$ & Diagnosis & Management & Outcome \\
\hline \multirow{4}{*}{$\begin{array}{l}\text { Day } 11-12 \\
\text { Respiratory distress }\end{array}$} & Pulmonary edema & $\begin{array}{l}\text { Mechanical ventilation } \\
\text { Diuretics }\end{array}$ & Resolved \\
\hline & Atrial fibrillation & Amiodarone/electrocardioversion & Resolved \\
\hline & Hypotension & $\begin{array}{l}\text { lonotropes } \\
\text { Ruled out cardiac problems/ pulmonary } \\
\text { embolism/sepsis }\end{array}$ & Improvement \\
\hline & COVID-19 PCR +ve & Low levels of calcineurin inhibitors, steroids & - \\
\hline \multirow{3}{*}{$\begin{array}{l}\text { Day } 13-22 \\
\text { Improvement in clinical } \\
\text { parameters }\end{array}$} & $\begin{array}{l}\text { X-ray chest improved with few } \\
\text { infiltrates }\end{array}$ & $\begin{array}{l}\text { Weaned off mechanical ventilation on day } 15 \\
\text { Enteral nutrition } \\
\text { Out of bed mobilisation }\end{array}$ & Improvement \\
\hline & $\begin{array}{l}\text { CT chest typical of } \\
\text { COVID-19 (Figure1) }\end{array}$ & Low levels of calcineurin inhibitors, steroids & Non responsive \\
\hline & High D-Dimers & Enoxaparin & Non responsive \\
\hline $\begin{array}{l}\text { Day } 23-26 \\
\text { Respiratory distress }\end{array}$ & $\begin{array}{l}\text { Severe COVID-19 related lung } \\
\text { injury } \\
\text { Hypotension } \\
\text { Abdominal collection }\end{array}$ & $\begin{array}{l}\text { Re-intubation with mechanical ventilation } \\
\text { Multiple ionotropes } \\
\text { EUS guided aspiration (+ve for COVID-19PCR) } \\
\text { 19PCR) }\end{array}$ & $\begin{array}{l}\text { Increasing oxygen } \\
\text { requirement } \\
\text { Non responsive } \\
\text { - }\end{array}$ \\
\hline $\begin{array}{l}\text { Day } 27 \\
\text { Cardiac arrest }\end{array}$ & $\begin{array}{l}\text { Hypoxemia } \\
\text { Metabolic acidosis } \\
\text { Shock }\end{array}$ & $\begin{array}{l}\text { High ventilator settings } \\
\text { Multiple ionotropes } \\
\text { Renal replacement therapy }\end{array}$ & Death \\
\hline
\end{tabular}


The impact of COVID-19 on liver transplant recipients remains unclear. From the limited available data, it can be assumed that transplanted patients with COVID-19 are at risk for unfavourable outcomes independent of time posttransplantation. It is important that judicious selection criteria are formulated with careful consideration to risk versus benefit in the times of COVID-19 pandemic.

\section{CONFLICT OF INTEREST:}

None of the authors have any potential conflict of interest.

\section{AUTHORS' CONTRIBUTION:}

ABHB: Contributed to design, concept, data collection, manuscript writing and critical revision.

SR: Contributed to data collection, manuscript writing and critical revision.

AA: Contributed to manuscript writing and critical revision.

\section{REFERENCES}

1. BhooriS, Rossi RE, CitterioD, MazzaferroV. COVID-19 in longterm liver transplant patients: Preliminary experience froman Italian transplant centrein lombardy. Lancet Gastroenterol Hepatol 2020; 5(6):532-3. doi: 10.1016/ S2468-1253(20)30116-3.

2. Webb GJ, Moon AM, Barnes E, Barritt AS, Marjot T. Determining risk factors for mortality in liver transplant patients with COVID-19. Lancet Gastroenterol Hepatol 2020; 5(7):P643-644. doi:http://doi.org/10.1016/S2468-1253 (20)30125-4.

3. Bhatti ABH, Dar FS, Butt MO, Sahaab E, Salih M, Shah NH, et al. Living donor liver transplantation for acute on chronic liver failure based on EASL-CLIF diagnostic criteria. J Clin Exp Hepatol 2018; 8(2):136-43. doi: 10.1016/j.jceh.2017. 11.007.

Abu Bakar Hafeez Bhatti ${ }^{1}$, Shahzad Riyaz ${ }^{2}$ and Aftab Akhtar ${ }^{3}$

${ }^{1}$ Department of Hepato-Pancreato-Biliary Surgery and Liver Transplantation, Shifa International Hospital, Islamabad, Pakistan

${ }^{2}$ Department of Hepatology, Shifa International Hospital, Islamabad, Pakistan

${ }^{3}$ Department of Pulmonology and Critical Care, Shifa International Hospital, Islamabad, Pakistan

Correspondence to: Dr. Abu Bakar Hafeez Bhatti, Department of Hepato-Pancreato-Biliary Surgery and Liver Transplantation, Shifa International Hospital Islamabad, Pakistan E-mail: abubakar.hafeez@yahoo.com

Received: June 11, 2020; Revised: June 24, 2020;

Accepted: June 30, 2020

DOI: https://doi.org/10.29271/jcpsp.2020.JCPSPCR.CR141 